\title{
Influence of meclofenamic acid on the initiation of parturition and lactation in the sow
}

\author{
Anoma D. Gooneratne, P. E. Hartmann and I. Barker* \\ Department of Biochemistry, University of Western Australia, Nedlands, \\ Western Australia 6009, and * Baconsfield Piggery, Bullsbrook, Western Australia, Australia
}

\begin{abstract}
Summary. The effect of inhibition of prostaglandin (PG) synthesis on the initiation of parturition was studied in 4 groups of 16 sows each. Oral administration of meclofenamic acid $(5.0 \mathrm{mg} / \mathrm{kg}$ body weight/day) on Days 112,113 and 114 of pregnancy significantly delayed parturition compared to controls $(P<0.001)$. Exogenous PGF- $2 \alpha$ after meclofenamic acid treatment synchronized parturition 20.4 $\pm 1 \mathrm{~h}$ later. Functional luteolysis as indicated by a decline in maternal progesterone levels began during meclofenamic acid treatment; the fall in progesterone was then arrested in sows treated only with meclofenamic acid. Meclofenamic acid treatment in late pregnancy modified the normal initiation of lactation, as indicated by the high concentration of lactose and low concentrations of protein and $\mathrm{Na}^{+}$in colostrum in treated sows compared to controls. We suggest that PG synthesis is required for the initiation of parturition in the sow and that luteal regression may involve two stages: the first which may be independent of prostaglandin, and the second, dependent on prostaglandin.
\end{abstract}

\section{Introduction}

The sow is totally dependent upon the production of progesterone from a functional corpus luteum for the successful maintenance of pregnancy (du Mesnil du Buisson \& Dauzier, 1957). In the sow, as in other corpus luteum-dependent species, the onset of parturition (Thorburn \& Challis, 1979) and lactation (Kuhn, 1969) are controlled by the factors which cause corpus luteum regression. The administration of prostaglandin (PG) F-2 $\alpha$ or its analogues causes a decline in plasma progesterone and induces premature parturition in sows in late pregnancy (Gustafsson, Einarsson, Larsson \& Edqvist, 1976; Wetteman, Hallford, Kreider \& Turman, 1977) while the inhibition of PG synthesis by indomethacin in late pregnancy delays the onset of parturition (Sherwood, Nara, Crnekovic \& First, 1979). However, the stimulus for the synthesis of PG and the mechanics of luteolysis in the late pregnant sow is as yet unclear.

This study investigates the influence of meclofenamic acid, a potent PG synthetase inhibitor (Flower, 1974), on luteolysis and the decline in plasma progesterone before parturition in the sow. In most species, including the sow, the initiation of parturition and of lactogenesis are closely associated in time (Fulkerson, 1979). Since the establishment of lactation is required for the survival of the offspring and progesterone withdrawal has been shown to play a key role in both the initiation of parturition and lactogenesis, the effects of the inhibition of PG synthesis on the initiation of lactation and composition of mammary secretion were also studied. 


\section{Materials and Methods}

Trials were conducted in a commercial piggery (Baconsfield Piggery, Bullsbrook, Western Australia) where intensive husbandry management procedures were followed. The 64 sows (Large White and Landrace pure and crossbreds) were selected on Day 112 of gestation and assigned to one of four treatment groups. A randomized block design was used in which sows were first allocated to blocks according to parity and then at random to treatments. The parity of the sows ranged from 1 to 8 and each group therefore contained 2 sows of the same parity. The sows were brought into individual farrowing crates 1 week before the expected date of farrowing, and maintained in the crate until weaning (3-4 weeks).

\section{Treatment}

The prostaglandin synthetase inhibitor meclofenamic acid (Arquel: Parke-Davis \& Co., New South Wales) was administered orally at a dose of $5.0 \mathrm{mg} / \mathrm{kg}$ body weight/day. Preliminary studies established that this dosage was sufficient to delay parturition without deleterious effects to the dam or the offspring. The fact that parturition occurred within $72 \mathrm{~h}$ of withdrawal of meclofenamic acid treatment suggested that this dosage was not greatly in excess.

Cloprostenol (Estrumate: I.C.I., Melbourne, Victoria), a synthetic PGF-2 $\alpha$, was injected $(200 \mu \mathrm{g}) \mathrm{i} . \mathrm{m}$. to induce parturition.

\section{Treatment groups}

Group 1. Meclofenamic acid was fed in a divided dose with the morning and afternoon meal on Days 112, 113 and 114 of pregnancy.

Group 2. The sows were treated with meclofenamic acid as in Group 1 and then injected with $200 \mu \mathrm{g}$ cloprostenol on Day 115 of pregnancy.

Group 3. The sows were treated as in Group 2, and then meclofenamic acid administration was resumed from the first meal after farrowing and continued for 3 days.

Group 4. These sows did not receive any treatment. The gestation length, time of farrowing and the litter sizes and weights at birth and at weaning were recorded for all the sows.

\section{Plasma and mammary secretion samples}

Blood and milk samples were collected from 4 sows in each treatment group. Blood was collected, from the start of treatment until 3 days post partum, from the ear vein, plasma was prepared immediately by centrifugation and stored at $-20^{\circ} \mathrm{C}$ until analysis. Mammary secretion $(2-3 \mathrm{ml})$ was collected from the 4 most anterior glands (right and left) for 5 days post partum. During the first 2 days of lactation milk was expressed manually; thereafter samples were collected after inducing milk let down with oxytocin (1 i.u. Pitocin: Parke-Davies).

Plasma progesterone assay. The concentration of progesterone in plasma was determined by radioimmunoassay, using antibodies raised in rabbits against progesterone-11-succinyl-bovine serum albumin, as described by Martin, Cake \& Hartmann (1980). All samples were extracted with 7 volumes of $n$-hexane and duplicate aliquots were assayed. Free and bound progesterone were separated with dextran-coated charcoal in $0.1 \%(\mathrm{w} / \mathrm{v})$ gelatin. The intra-assay and inter-assay coefficients of variation were 5.5 and $8.4 \%$ respectively. The sensitivity of the standard curve was $0.005 \mathrm{ng}$.

$\left[1,2-{ }^{3} \mathrm{H}\right]$ Progesterone $(>50 \mathrm{Ci} / \mathrm{mmol})$ was obtained from the Radiochemical Centre, Amersham, Bucks, U.K., and the non-radioactive progesterone, grade A, was obtained from Calbiochem, Los Angeles, California U.S.A. 
Analysis of mammary secretion. The concentration of lactose in milk was measured by the method of Kuhn \& Lowenstein (1967). The milk protein content was estimated by the method described by Lowry, Rosebrough, Farr \& Randall (1951). Milk fat was estimated as total esterified fatty acids (Hartmann, 1973), assuming the mean molecular weight of sow milk fatty acids to be 266 (De Man \& Bowland, 1963).

Determinations of $\mathrm{Na}^{+}$and $\mathrm{K}^{+}$were carried out on an atomic absorption spectrophotometer (Varian Techtron, model 1200) as described by Gooneratne, Hartmann, McCauley \& Martin (1979).

\section{Statistical analysis}

All results were analysed statistically using a one-way or two-way analysis of variation and Student's $t$ test (Snedecor \& Cochran, 1972).

\section{Results}

The administration of meclofenamic acid alone (Group 1) or in combination with PG (Groups 2 and 3 ) significantly delayed parturition $(P<0.001)$ compared with controls (Group 4) (Table 1). However, there was no significant difference in length of gestation in Groups 1,2 and 3 . The gestation length of control sows was similar to that obtained for 3682 sows farrowing over, a period of 3 years in the same piggery $(114.55 \pm 1.5$ days; mean \pm s.d.). The sows in Group 1 farrowed 15-72 h after the last dose of meclofenamic acid, while those in Groups 2 and 3 littered $20.42 \pm 1.0 \mathrm{~h}$ (mean \pm s.e.m.) after the injection of PG and over a period of only $35 \mathrm{~h}$.

Table 1. Effects of treatment of late pregnant sows with cloprostenol (PG) and/or meclofenamic acid (MFA)

\begin{tabular}{|c|c|c|c|c|c|c|}
\hline \multirow[b]{3}{*}{ Treatment } & \multirow{3}{*}{$\begin{array}{l}\text { Gestation } \\
\text { length } \\
\text { (days) }\end{array}$} & \multicolumn{3}{|c|}{ Litter size } & \multirow{2}{*}{\multicolumn{2}{|c|}{ Litter weights (kg) }} \\
\hline & & & & & & \\
\hline & & Liveborn & Stillborn & At weaning & At birth & At weaning \\
\hline $\begin{array}{l}\text { Group 1 } \\
\quad \text { (MFA) }\end{array}$ & $\begin{array}{r}* 116.03 \\
\pm 0.22\end{array}$ & $\begin{array}{r}10.38 \\
+0.59\end{array}$ & $\begin{array}{r}0.89 \\
\pm 0.39\end{array}$ & $\begin{array}{r}9.01 \\
\pm 0.38\end{array}$ & $\begin{array}{r}13.40 \\
\pm 0.85\end{array}$ & $\begin{array}{r}35.08 \\
\pm 2.36\end{array}$ \\
\hline $\begin{array}{l}\text { Group } 2 \\
\quad \text { (MFA + PG) }\end{array}$ & $\begin{array}{r}* 115.88 \\
\pm 0.09\end{array}$ & $\begin{array}{r}9.63 \\
\pm 0.55\end{array}$ & $\begin{array}{r}1.30 \\
\pm 0.39\end{array}$ & $\begin{array}{r}8.75 \\
+0.28\end{array}$ & $\begin{array}{r}12 \cdot 19 \\
\pm 0 \cdot 70\end{array}$ & $\begin{array}{r}35.01 \\
\pm 2.23\end{array}$ \\
\hline $\begin{array}{l}\text { Group } 3 \\
\quad(\text { MFA }+P G+\text { MFA) }\end{array}$ & $\begin{array}{r}{ }^{*} 116.00 \\
\pm 0.09\end{array}$ & $\begin{array}{r}10.63 \\
\pm 0.76\end{array}$ & $\begin{array}{r}0.75 \\
\pm 0.23\end{array}$ & $\begin{array}{r}8.63 \\
\pm 0.61\end{array}$ & $\begin{array}{r}13 \cdot 19 \\
\pm 0.98\end{array}$ & $\begin{array}{r}34.62 \\
\pm 2.82\end{array}$ \\
\hline $\begin{array}{l}\text { Group } 4 \\
\quad \text { (control) }\end{array}$ & $\begin{array}{r}114.38 \\
\pm 0.24\end{array}$ & $\begin{array}{r}10 \cdot 13 \\
\pm 0 \cdot 38\end{array}$ & $\begin{array}{r}0.54 \\
+0.18\end{array}$ & $\begin{array}{r}8.88 \\
+0.38\end{array}$ & $\begin{array}{r}12 \cdot 86 \\
\pm 0 \cdot 48\end{array}$ & $\begin{array}{r}35.53 \\
\pm 1.34\end{array}$ \\
\hline
\end{tabular}

Values are mean \pm s.e.m. for 16 sows/group.

* Significantly different from value for Group 4 (P<0.001).

Litter size (live and still births) and weights at birth and at weaning (Table 1) showed no significant differences between the four groups. A few sows in Group 1 had prolonged farrowings. However, none of these sows required assistance and no other side effects to meclofenamic acid or PG administration were observed.

The changes in plasma progesterone concentrations from Day 112 of pregnancy until 3-4 days post partum for individual sows from each group are shown in Text-fig. 1. A decline in plasma progesterone concentration was observed in 10 out of 12 sows during meclofenamic acid 


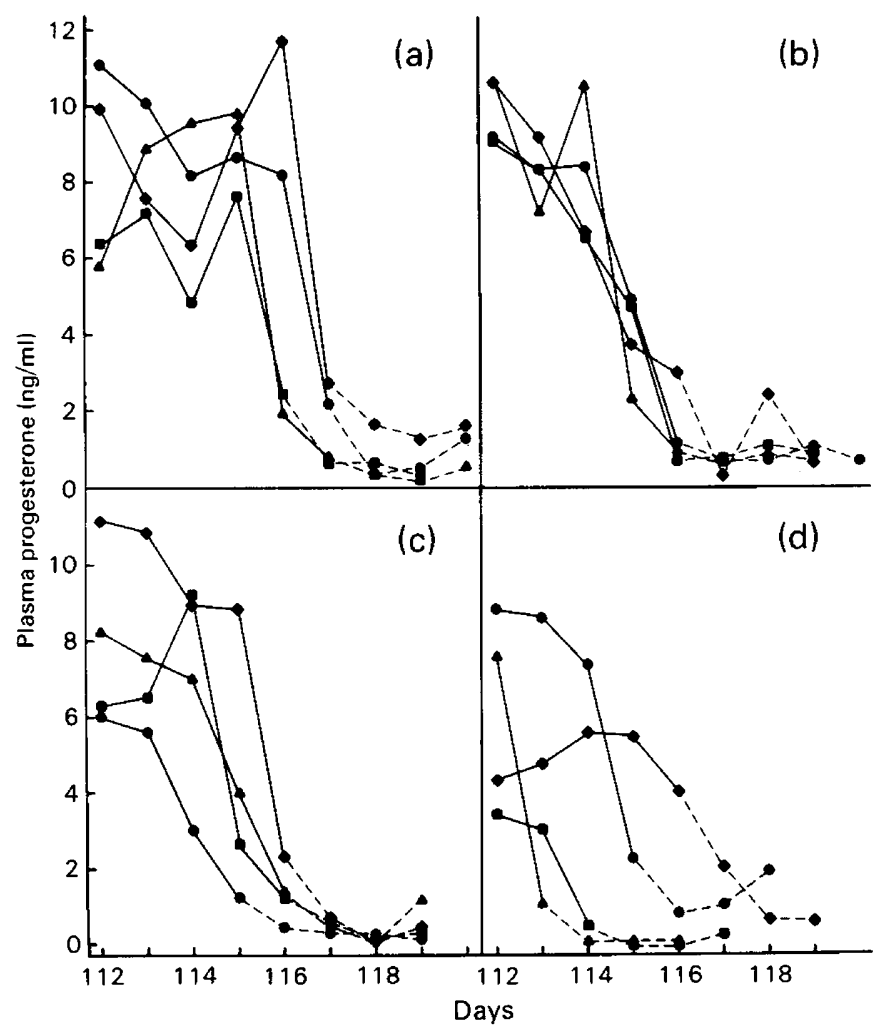

Text-fig. 1. The changes in plasma progesterone concentration up to parturition (unbroken lines) and after parturition (broken lines) for 4 sows from each of the treatment groups: (a) Group 1 (meclofenamic acid, MFA), (b) Group 2 (MFA + cloprostenol (PG)), (c) Group 3 (MFA + PG + MFA), (d) Group 4 (controls).

treatment (Groups 1, 2 and 3) and mean progesterone level on Day 114 was significantly lower $(P<0.05)$ than at the start of treatment on Day 112 of pregnancy. The administration of $P G$ on Day 115 was followed by a decline in plasma progesterone levels (Text-figs $1 \mathrm{~b}$ and $\mathrm{c}$ ). However, in Group 1 sows, after the initial decline an elevation in plasma progesterone concentration was observed (Text-fig. 1a) which lasted for $24-48 \mathrm{~h}$. On the day of parturition, no significant differences in progesterone concentrations between the four groups were observed.

The composition analyses of colostrum showed that values for lactose were increased and values for protein and $\mathrm{Na}^{+}$were decreased in sows in Groups 1,2 and 3 compared with controls (Table 2). The Group 3 sows had elevated fat concentrations in colostrum. From Day 1 post partum all sows (treated and control) showed similar changes in milk composition.

Table 2. The concentrations of major constituents of colostrum from sows treated with cloprostenol (PG) and/or meclofenamic acid (MFA)

\begin{tabular}{|c|c|c|c|c|}
\hline $\begin{array}{c}\text { Milk } \\
\text { constituent }\end{array}$ & $\begin{array}{l}\text { Group } 1 \\
\text { (MFA) }\end{array}$ & $\begin{array}{c}\text { Group 2 } \\
\text { (MFA + PG) }\end{array}$ & $\begin{array}{c}\text { Group } 3 \\
\text { (MFA + PG + MFA) }\end{array}$ & $\begin{array}{l}\text { Group } 4 \\
\text { (control) }\end{array}$ \\
\hline Lactose $(\mathrm{g} / \mathrm{l})$ & $33 \cdot 70 \pm 2 \cdot 0$ & $33 \cdot 20 \pm 4 \cdot 0$ & $37.73 \pm 5.0$ & $27.34 \pm 2.0$ \\
\hline Protein $(\mathrm{g} / \mathrm{l})$ & $112.75 \pm 25.0$ & $123.82 \pm 31.0$ & $112.62 \pm 45.0$ & $225.76 \pm 28.0$ \\
\hline Fat $(g / l)$ & $48 \cdot 36 \pm 6 \cdot 0$ & $42.88 \pm 7.0$ & $81 \cdot 31 \pm 15 \cdot 0$ & $43.85 \pm 4.0$ \\
\hline $\mathrm{Na}^{+}(\mathrm{mM})$ & $28.56 \pm 5.2$ & $27 \cdot 38 \pm 2 \cdot 2$ & $22.75 \pm 3.0$ & $43 \cdot 14 \pm 17 \cdot 3$ \\
\hline $\mathrm{K}^{+}(\mathrm{mM})$ & $27.84 \pm 5.0$ & $29 \cdot 50 \pm 3 \cdot 0$ & $32.96 \pm 4.6$ & $28.03 \pm 3.2$ \\
\hline $\mathrm{Ca}^{++}(\mathrm{mm})$ & $14 \cdot 26 \pm 1 \cdot 0$ & $23 \cdot 29 \pm 5 \cdot 0$ & $18.49 \pm 2.0$ & $20 \cdot 32 \pm 5 \cdot 0$ \\
\hline
\end{tabular}




\section{Discussion}

In the sow, parturition is preceded by the regression of the corpus luteum of pregnancy and the withdrawal of progesterone from the maternal circulation (Ash \& Heap, 1975). The initiation of parturition was significantly delayed $(P<0.001)$ in all meclofenamic acid-treated sows. However, the concentration of progesterone in peripheral plasma declined during the administration of meclofenamic acid (Text-fig. 1), suggesting that functional luteolysis (reduction or termination of progesterone secretion; First \& Bosc, 1979) can occur while prostaglandin synthesis is depressed. Nevertheless, the possibility that increased catabolism of progesterone occurred at this time cannot be dismissed.

There was a transient rise in progesterone levels for $24-48 \mathrm{~h}$ following the initial decline in Group 1 sows. In contrast, when PG was administered exogenously (Groups 2 and 3), plasma progesterone levels continued to drop and farrowing was synchronized about $20 \mathrm{~h}$ later. This interval between PG injection and farrowing is shorter than that observed when parturition was induced with PGF-2 $\alpha$ or its analogues (Ash \& Heap, 1973; Gustafsson et al., 1976), suggesting that the progesterone decline observed during meclofenamic acid treatment represented the initiation of luteal regression. In this connection Silver et al. (1979) observed that the gradual decline in plasma progesterone before parturition was not associated with the rise in PG concentrations.

The ability of exogenous PGF- $2 \alpha$ to cause luteal regression in a number of species, including the sow, is well established (Hansel, 1975). However, there is no definitive evidence that PGs are the cause of normal regression of the corpus luteum just before parturition in the sow (see review by Dziuk, 1977). The results from this study indicate some luteolytic action of PG before parturition. The arrest in the fall of progesterone in Group 1 sows and the significant delay in parturition in all treated animals indicate that PG is necessary for the complete withdrawal of progesterone and the initiation of parturition. However, as demonstrated by the use of meclofenamic acid, functional luteolysis will begin even when PG synthesis is depressed. These findings suggest that luteal regression in the sow may involve two phases, as in the sheep (Baird \& Scaramuzzi, 1975), the first of which may be independent of PG and the second, dependent on PG. However, further studies are required to establish the functional changes in the corpus luteum during late pregnancy in the sow.

Prostaglandins play a role in maintaining uterine tone and motility (Williams \& Vane, 1975) and the softening and dilatation of the cervix (Liggins, Fairclough, Grieves, Forster \& Knox, 1977). The difficulty in parturition experienced by some Group 1 sows even after the decline in progesterone concentrations may be due to the residual effects of meclofenamic acid on the uterus and cervix (Mitchell \& Flint, 1978).

As lactose is one of the specific components of milk, the appearance of lactose in the mammary gland can be used as an indicator of lactogenesis (Yokoyama, Shinde \& Ota, 1969). The presence of increased concentrations of lactose and decreased concentrations of protein and $\mathrm{Na}^{+}$in colostrum suggest an early initiation of lactation in meclofenamic acid-treated sows (Groups 1, 2 and 3). Although parturition was delayed, the administration of progesterone alone or in combination with PG to late pregnant sows did not alter the composition of mammary secretion at farrowing compared with that in controls (Gooneratne et al., 1979). Since a withdrawal in plasma progesterone concentration before parturition is considered to be the hormonal signal for lactogenesis (Kuhn, 1969), the early initiation of lactation may be related to the decline in progesterone observed during meclofenamic acid treatment. In addition, studies in goats (Maule Walker \& Peaker, 1980) suggested that PGs produced in the mammary gland may play a local inhibitory role in the control of lactogenesis and copious milk secretion. Therefore, further study is necessary to determine the influence of the presence or absence of PGs and the withdrawal of progesterone on the initiation of lactation in the sow. The growth rate of piglets from meclofenamic acid-treated sows was similar to that of controls, suggesting that normal lactation was established in all sows. 
The present study indicates that treatment with meclofenamic acid followed by PG can be successfully used to synchronize parturition without deleterious effects to the sow or the piglets. In contrast to lowered birth weights observed during the premature induction of parturition (Wetteman et al., 1977) meclofenamic acid treatment did not affect piglet weights at birth. Since meclofenamic acid can be administered orally with the diet, it would be commercially more acceptable than progesterone which was injected in a previous study of synchronization of farrowing in sows (Gooneratne et al., 1979). In this connection further studies on the administration of oral progestagens would be of interest for this method of synchronization of farrowing in sows.

We thank Miss H. M. Nottage for technical assistance. This work was supported by a grant from the Australian Pig Industry Research Committee.

\section{References}

Ash, R.W. \& Heap, R.B. (1973) The induction and synchronization of parturition in sows treated with I.C.I. 79939, an analogue of prostaglandin F2 $\alpha$. $J$. agric. Sci. Camb. 81, 365-368.

Ash, R.W. \& Heap, R.B. (1975) Oestrogen, progesterone and corticosteroid concentrations in peripheral plasma of sows during pregnancy, parturition, lactation and after weaning. J. Endocr. 64, 141-154.

Baird, D.T. \& Scaramuzzi, R.J. (1975) Prostaglandin F2 $\alpha$ and luteal regression in the ewe: comparison with 16-aryloxyprostaglandin (I.C.I. 80996). Annals Biol. anim. Biochim. Biophys. 15, 161-174.

De Man, J.M. \& Bowland, J.P. (1963) Fatty acid composition of sow's colostrum, milk and body fat as determined by gas liquid chromatography. J. Dairy Res. 30, 339-343.

du Mesnil du Buisson, F. \& Dauzier, L. (1957) Influence de l'ovariectomie chez la Trui pendant la gestation. C. r. Séanc. Soc. Biol. 151, 311-313.

Dziuk, P.J. (1977) Reproduction in pigs. In Repro duction in Domestic Animals, 3rd edn, pp. 472-. Eds H. H. Cole \& P. T. Cupps. Academic Press, New York.

First, N.L. \& Bosc, M.J. (1979) Proposed mechanisms controlling parturition and the induction of parturition in swine. J. Anim. Sci. 48, 1407-1421.

Flower, R.J. (1974) Drugs which inhibit prostaglandin biosynthesis. Pharmacol. Rev. 26, 33-67.

Fulkerson, W.J. (1979) Initiation of lactation. In Hormonal Control of Lactation 1, pp. 22-35. Ed. D. F. Horrobin. Churchill Livingstone, Edinburgh.

Gooneratne, A., Hartmann, P.E., McCauley, I. \& Martin, C.E. (1979) Control of parturition in the sow using progesterone and prostaglandin. A ust. J. biol. Sci. 32, 587-595.

Gustafsson, B., Einarsson, S., Larsson, K. \& Edqvist, L.E. (1976) Sequential changes of oestrogens and progesterone at prostaglandin induced parturition in the sow. Am.J. vet. Res. 37, 1017-1020

Hansel, W. (1975) Luteal regression in domestic animals. Annls Biol. anim. Biochim. Biophys. 15, 147-160.

Hartmann, P.E. (1973) Changes in the composition and yield of mammary secretion of cows during the initiation of lactation. J. Endocr. 59, 231-247.

Kuhn, N.J. (1969) Progesterone withdrawal as the lactogenic trigger in the rat. J. Endocr. 44, 49-54.

Kuhn, N.J. \& Lowenstein, J.M. (1967) Lactogenesis in the rat. Changes in metabolic parameters at parturition. Biochem. J. 105, 995-1002.
Liggins, G.C., Fairclough, R.J., Grieves, S.A., Forster, C.S. \& Knox, B.S. (1977) Parturition in the sheep. In The Fetus and Birth (Ciba Fdn. Symp. No. 47), pp. 5-25. Eds J. Kinght \& M. O'Conner. Elsevier, Amsterdam.

Lowry, O.H., Rosebrough, N.J., Farr, A.L. \& Randall, R.J. (1951) Protein measurement with the folin phenol reagent. J. biol. Chem. 193, 265-275.

Martin, C.E., Cake, M.H. \& Hartmann, P.E. (1980) Corticosteroids and progesterone in amniotic fluid and maternal plasma of the rat and their relation to parturition. J. dev. Physiol. 2, 1-9.

Maule Walker, F.M. \& Peaker, M. (1980) Local production of prostaglandins in relation to mammary function at the onset of lactation in the goat. $J$. Physiol., Lond. 309, 65-79.

Mitchell, M.D. \& Flint, A.P.F. (1978) Use of meclofenamic acid to investigate the role of prostaglandin biosynthesis during induced parturition in sheep. $J$. Endocr. 76, 101-109.

Sherwood, O.D., Nara, B.S., Crnekovic, V.E. \& First, N.L. (1979) Relaxin concentrations in pig plasma after the administration of indomethacin and PGF2 $\alpha$ during late pregnancy. Endocrinology 104, 17161721 .

Silver, M., Barnes, R.J., Comline, R.S., Fowden, A.L., Clover, L. \& Mitchell, M.D. (1979) Prostaglandins in the foetal pig and prepartum endocrine changes in mother and foetus. Anim. Reprod. Sci. 2, 305-322.

Snedecor, G.W. \& Cochran, W.G. (1972) Statistical Methods, 6th edn. Iowa State University Press, Ames.

Thorburn, G.D. \& Challis, J.R. (1979) Endocrine control of parturition. Physiol. Rev. 59, 863-918.

Wetteman, R.P., Hallford, D.M., Kreider, D.L. \& Turman, E.J. (1977) Influence of prostaglandin F2a on endocrine changes at parturition in gilts. J. A nim. Sci. 44, 106-110.

Williams, K.I. \& Vane, J.R. (1975) Inhibition of uterine motility. The possible role of prostaglandins and aspirin-like drugs. Pharmacol. Ther, B. 1, 89-93.

Yokoyama, A., Shinde, Y. \& Ota, K. (1969) Endocrine control of changes in lactose content of the mammary gland in rats shortly before and after parturition. In Lactogenesis: The initiation of Milk Secretion at Parturition, pp. 65-71. Eds M. Reynolds \& S. J. Folley. University of Pennyslvania

Press, Philadelphia.
Downtoaded from Bioscientifica. com at $04 / 26 / 2023$ 03;
Received 2 July 1981 